\title{
Kajian Tipologi Pedesaan Dalam Mengatasi Disparitas Wilayah Perbatasan Kecamatan Paloh
}

\author{
Nana Novita Pratiwi ${ }^{\text {a }}$ \\ a Jurusan Perencanaan Wilayah dan Kota, Fakultas Teknik, Universitas Tanjungpura, Pontianak, Indonesia \\ E-mail Korespondensi: asgarnana@gmail.com; nananovita@teknik.untan.ac.id
}

\begin{abstract}
Abstrak: Kecamatan Paloh merupakan wilayah perbatasan yang cukup strategis dan potensial dalam pengembangan pusat-pusat layanan dan kegiatan ekonomi lokal. Namun demikian, Paloh memiliki angka disparitas tertinggi dibandingkan dengan wilayah lain di Kabupaten Sambas. Tujuan penelitian ini yaitu mengkaji tipologi pedesaan untuk mengatasi disparitas wilayah di perbatasan. Adapun sasaran penelitian ini yaitu mengidentifikasi kondisi disparitas, mengidentifikasi tipologi desa, dan mengkaji faktor-faktor yang memengaruhi perkembangan wilayah di Kecamatan Paloh. Metode yang digunakan dalam penelitian ini yaitu mixed method. Berdasarakan hasil kajian dapat disimpulkan bahwa disparitas Kecamatan Paloh masih tergolong kecil namun mengalami pertumbuhan indeks yang semakin ting $i$ dalam lima tahun terakhir. Menurut tipologinya, Kecamatan Paloh termasuk desa pesisir dataran rendah di Perdesaan dengan tingkat perkembangan desa Swakarsa yaitu desa-desa yang sedang mengalami perkembangan sedang dalam segala bidang terkait dengan aspek sosial dan ekonomi. Kecamatan Paloh memiliki sumber daya alam terutama di sektor kelautan yang sangat besar. Faktor-faktor yang dianggap kurang mendukung perkembangan wilayah di Kecamatan Paloh antara lain ketersediaan infrastruktur. Khususnya pada akses jalan dan sarana prasarana pengembangan ekonomi, sehingga berpengaruh pada rendahnya peluang usaha dan rendahnya mobilitas orang dan barang baik dari luar ke dalam maupun dari dalam keluar.
\end{abstract}

Kata Kunci: desa, disparitas, wilayah, Paloh

How to cite (APA 6th Style):

Pratiwi, Nana Novita. (2020). Kajian Tipologi Pedesaan Dalam Mengatasi Disparitas Wilayah Perbatasan Kecamatan Paloh, 1(1), 3139. doi: 10.26418/uniplan.v1i1.43049

\section{PENDAHULUAN}

Kawasan perbatasan merupakan manifestasi utama kedaulatan wilayah suatu Negara yang memiliki peranan penting dalam penentuan batas wilayah kedaulatan, pemanfaatan sumber daya alam, menjaga keamanan dan keutuhan wilayah (Muta'ali, 2014). Karakteristik wilayah termasuk kawasan perbatasan diambil berdasarkan unit desa dengan berbagai tipologinya masing-masing, sebagaimana yang diamatkan dalam PP No 72 Tahun 2005 bahwa tipologi desa merupakan gambaran spesifik keunggulan potensi desa/kelurahan baik berdasarkan sumber daya alam, sumber daya manusia, kelembagaan serta infrastruktur dalam menentukan arah pengembangan dan pembinaan masyarakat.

Kalimantan Barat merupakan salah satu provinsi dengan beberapa kecamatan yang termasuk dalam wilayah perbatasan Malaysia serta menjadi lokasi prioritas Pusat Kegiatan Strategis Nasional (RTRWN 20002020). Salah satu kecamatan tersebut adalah Kecamatan Paloh Kabupaten Sambas. Sebagai PKSN, Kecamatan Paloh masih memiliki beberapa permasalahan yang belum ditangani secara tuntas. Menurut Husnadi (2006), kegiatan pembangunan di kawasan perbatasan, khususnya Kecamatan Paloh belum dikelola dan belum adanya konsepsi pembangunan yang jelas dan terintegrasi. Selain itu, pengembangan kawasan perbatasan masih diatasi secara umum tanpa melihat karakteristik pada masing-masing desa. Padahal kita ketahui bahwa setiap desa yang terdapat di bagian wilayah memiliki potensi, masalah dan isu pengembangan yang berbeda-beda.

Jika ditinjau secara ekonomi, efektivitas kegiatan ekonomi di Kecamatan Paloh masih sangat rendah. Hal ini dapat dilihat dari rendahnya produktivitas masyarakat dan tingginya kesenjangan ekonomi terlebih dengan Negara tetangga yang mencapai hingga \pm US $\$ 3.700$ ditahun 2000 (Thontowi, 2009). Secara fisik Kecamatan Paloh tidak dilengkapi dengan penyediaan infrastruktur yang memadai. Berdasarkan data BPS 
2014, 75\% jalan yang terdapat di Kecamatan Paloh merupakan jalan tanah dalam kondisi buruk. Lebih dari itu, pelayanan fasilitas, terutama fasilitas pendidikan dan kesehatan juga masih sangat terbatas dimana sebagian besar masyarakatnya masih dilayani hingga keluar desa dan kecamatan. Selain itu, secara sosial kependudukan kualitas SDM manusia di Kecamatan Paloh masih sangat rendah dimana berdasarkan Bappeda Kabupaten Sambas, 84,55\% masyarakat hanya berpendidikan SD atau bahkan tidak pernah tamat SD (Husnadi, 2006).

\section{TINJAUAN PUSTAKA}

\subsection{Konsep Pembangunan Wilayah}

Menurut Todaro (2000), pembangunan harus dipandang sebagai proses multidimensional yang mencakup berbagai perubahan mendasar atau struktur sosial, sikap-sikap masyarakat dan institusi-institusi nasional, disamping tetap mengejar akselerasi pertumbuhan ekonomi, penanganan ketimpangan pendapatan serta pengentasan kemiskinan.

Hal tersebut dipertegas oleh Anwar (2001), bahwa konsep pembangunan wilayah mengacu pada pemerataan (equity), mendukung pertumbuhan ekonomi (efficiency) dan berkelanjutan (sustainability). Pandangan lain yang lebih optimistik mengenai pembangunan wilayah diungkapkan oleh Hayami dan Ruttan (1971) bahwa model pembangunan wilayah yang dikenal dengan "induced innovation model" merupakan bentuk-bentuk pengembangan sumber daya alam dengan memanfaatkan teknologi dalam mengantisipasi masalah kelangkaan.

Pada perkembangannya, terjadi pergeseran paradigma dalam memandang konsep pembangunan wilayah. Menurut Murty (2000), pembangunan wilayah yang berimbang tidak mengharuskan adanya kesamaan tingkat pembangunan antar daerah (equally developed), juga tidak menuntut pencapaian tingkat industralisasi wilayah/daerah yang seragam. Konsep pembangunan wilayah yang berimbang adalah terpenuhinya potensi-potensi pembangunan sesuai dengan kapasitas pembangunan setiap wilayah/daerah yang jelas beragam.

\subsection{Konsep Ketimpangan Wilayah}

Menurut G. Kartasasmita (1996), kesenjangan wilayah disebabkan karena:

a. Lemahnya keterkaitan kegiatan ekonomi antar daerah perkotaan dan daerah perdesaan.

b. Keterbatasan sumber daya manusia yang berkualitas di daerah perdesaan, sehingga menyebabkan rendahnya produktivitas dan kemampuan masyarakatnya untuk berpartisipasi secara aktif dalam pembangunan.

c. Kurangnya prasarana dan sarana perhubungan di daerah perdesaan, khsusnya prasarana dan sarana yang menghubungkan suatu kawasan miskin dengan daerah-daerah yang lebih maju.

Lebih dari itu, Williamson (1965) merumuskan bahwa kesenjangan atau ketimpangan antar daerah yang semakin besar disebabkan karena:

a. Adanya migrasi tenaga kerja terdidik yang memiliki kemampuan tinggi dan produktif antar daerah.

b. Adanya migrasi kapital antar daerah, adanya proses aglomerasi pada daerah yang relatif kaya sehingga menyebabkan daya tarik tersendiri bagi investor pada daerah lain, berakibat pada aliran kapital kedaerah yang memang sudah lebih dahulu maju.

Beberapa teori (teori Sektor oleh Williamson, 1965 dan Kuznets, 1955) menunjukan bahwa kesenjangan akan dapat seimbang dengan sendirinya tanpa campur tangan pemerintah. Tetapi dalam prakteknya, sebagaimana yang dikemukakan oleh Glasson (1977), bahwa kecenderungan wilayah yang menunjukan kondisi seimbang ini juga dibatasi oleh mobilitas perpindahan faktor antara sektor-sektor dan antara dampak terhadap pertumbuhan daerah-daerah dan ketidakmampuan daerah terhadap kemakmuran pertumbuhan.

Menurut Williamson, dinamika ketimpangan diawal pertumbuhan wilayah akan menunjukan indeks yang kecil, namun seiring berkembangnya wilayah tersebut, ketimpangan akan meningkat hingga pada titik tertentu ketika wilayah sudah menunjukan kestabilan pertumbuhan maka ketimpangan akan menurun kembali (Nurzaman, 2012) 
Ketimpangan wilayah tersebut disebabkan oleh adanya market failure yang dipengaruhi oleh beberapa faktor (Sayogyo, 1992 dalam Umbu, 2001), antara lain: 1). Rendahnya sumber daya manusia baik secara kualitas maupun kuantitas; 2). Sempitnya kesempatan dan peluang usaha di perdesaan; 3). Infrastruktur perdesaan yang tidak memadai untuk pengembangan industri; 4). Pola penguasaan tanah sebagai alat produksi vital di desa timpang dan 5). Berbagai sebab di mana penciptaan output ekonomi perdesaan serta distribusinya mengalami hambatan pemasaran akibat terdesak oleh produk industri.

\subsection{Karakteristik Wilayah Perdesaan}

Yayuk dan Mangku (2003) menjelaskan bahwa Desa merupakan tempat tinggal, asal, tanah leluhur yang merujuk pada satu kesatuan hidup dengan kesatuan norma serta batasan yang jelas. Pengertian lain tentang desa diuraikan oleh Kuntjaraningrat (1977) yang menyebutkan bahwa desa adalah sebagai komunitas kecil yang menetap disuatu daerah yang dimukim oleh para petani. Landis dalam Sumpeno (2011) juga menguraikan pengertian desa dalam tiga aspek, (1) analisis statistik, desa didefinisikan sebagai suatu lingkungan dengan penduduk kurang dari 2500 orang, (2) analisis sosial psikologis, desa merupakan suatu lingkungan yang penduduknya memiliki hubungan akrab danbersifat informal diantara sesama warganya, serta (3) analisis ekonomi, desa didefinisikansebagai suatu lingkungan dengan penduduknya tergantung kepada pertanian.

Sementara itu, secara hukum batasan tentang perdesaan ditemukan dalam UU No 26 Tahun 2007 tentang Penataan Ruang dan PP No 26 Tahun 2008 tentang RTRWN, dengan menyebutkan desa kedalam wilayah dan fungsi yang lebih luas, yaitu wilayah yang mempunyai kegiatan utama pertanian termasuk pengelolaan sumberdaya alam dengan susunan fungsi kawasan sebagai tempat permukiman perdesaan, pelayanan jasa pemerintahan, pelayanan sosial dan kegiatan ekonomi. Tarigan (2003) mengungkapkan bahwa desa dan perdesaan sering dikaitkan dengan pengertian rural dan village yang dibandingkan dengan kota (town/city) dan perkotaan (urban), dimana desa bukan sekedar unit adminstratif atau hanya permukiman penduduk, melainkan juga merupakan basis sumberdaya ekonomi, komunitas yang memiliki keragaman nilai-nilai lokal dan ikatan-ikatan sosial ataupun basis kepemerintahan yang mengatur dan mengurus sumberdaya dan komunitas tersebut.

Beberapa tipologi desa sebagaimana yang dijelaskan oleh Mut'ali (2013), yaitu:

1. Desa berdasarkan aspek lingkungan fisik: Desa pegunungan, perbukitan, pesisir/pantai, daratan dan pulau-pulau kecil.

2. Desa berdasarkan aspek posisi geografis terhadap pusat pertumbuhan kota: desa di kota, pinggiran kota, koridor antar kota, perdesaan dan terisolir

3. Desa berdasarkan aspek spasial: menyusur sepanjang pantai, terpusat, linier dataran rendah dan mengelilingi fasilitas tertentu.

4. Desa berdasarkan tingkat perkembangan: desa swadaya, swakarya dan swasembada.

\section{DATA DAN METODOLOGI}

Pendekatan yang digunakan dalam studi ini adalah mix methods yang menyelaraskan pendekatan induktif dan deduktif untuk merumuskan tipologi dalam pengembangan wilayah kawasan perbatasan dengan unit analisis desa. Beberapa proses dan langkah analisis dalam pendekatan ini, sebagai berikut:

1. Mengetahui gambaran disparitas Kecamatan Paloh. Kajian ini dilakukan dengan membandingkan wilayah studi (Kecamatan Paloh) dengan wilayah eksternal (kecamatan lain yang ada di Kabupaten Sambas) dengan model analisis indeks Williamson (Kuncoro, 2004).

2. Merumuskan tipologi desa berdasarkan 4 (empat) aspek berdasarkan teori Muta'ali yaitu aspek lingkungan fisik, aspek posisi geografis terhadapa pusat pertumbuhan kota, aspek spasial serta aspek pertumbuhan wilayah menurut instruksi Menteri Dalam Negeri No 11 Tahun 1972 tentang Pelaksanaan Klasifikasi dan Tipologi Desa di Indonesia. Tipologi desa dilakukan dengan teknik analisis evaluative melalui komparasi teori dengan kondisi eksisting. Sementara untuk aspek pertumbuhan wilayah dilakukan dengan rumus sturgess (dalam Sugiyono, 2005). 
3. Mengetahui faktor-faktor yang signifikan berpengaruh terhadap disparitas wilayah dengan analisis deskribtif. Menurut rumusan teori berdasarkan apa yang telah dikemukakan oleh Sayogyo, 1992 (dalam Umbu, 2001), G. Kartasasmita (1996) dan Williamson (1965), dimana faktor yang dianggap mempengaruhi ketimpangan antara lain adalah faktor SDA dan lingkungan, SDM, ketersediaan infrastruktur dan peluang usaha, demografis dan mobilitas sosial.

4. Mengetahui faktor-faktor yang signifikan berpengaruh terhadap disparitas wilayah dengan analisis deskribtif. Menurut rumusan teori berdasarkan apa yang telah dikemukakan oleh Sayogyo, 1992 (dalam Umbu, 2001), G. Kartasasmita (1996) dan Williamson (1965), dimana faktor yang dianggap mempengaruhi ketimpangan antara lain adalah faktor SDA dan lingkungan, SDM, ketersediaan infrastruktur dan peluang usaha, demografis dan mobilitas sosial.

\section{HASIL DAN PEMBAHASAN}

\subsection{Disparitas Kecamatan Paloh Terhadap Kabupaten Sambas}

Disparitas Kecamatan Paloh terhadap Kabupaten Sambas dikaji untuk melihat bagaimana kedudukan pembangunan Kecamatan Paloh secara makro regional. Kajian ini dilakukan dengan membandingkan wilayah studi (Kecamatan Paloh) dengan wilayah eksternal (kecamatan lain yang ada di Kabupaten Sambas) dengan mengkomparasikan beberapa model analisis, yaitu modifikasi indeks Williamson (Kuncoro, 2004).

Berdasarkan perhitungan Indeks Williamson Tahun 2010, IW Kecamatan Paloh adalah sebesar 0,18 dan meningkat menjadi 0,39 pada tahun 2015. Jika dilihat secara umum, angka ketimpangan berdasarkan Indeks Williamson Kecamatan Paloh terhadap Kabupaten Sambas tergolong sangat kecil yaitu mendekati 0 (nol), namun terjadi peningkatan indeks selama lima tahun terakhir. Fakta kecilnya angka ketimpangan tersebut mengindikasikan bahwa pendapatan masyarakat Paloh sudah cukup besar dan dapat memberikan kontribusi yang besar pula pada daerah.

Namun demikian, jika dikaitkan dengan kondisi infrastruktur terutama jalan yang dapat merepresentasikan perkembangan dinamika sosial ekonomi masyarakat, Kecamatan Paloh masih belum memberikan pelayanan akses yang cukup baik terutama akses yang menghubungkan pusat kecamatan dengan Desa Temajok. Selain itu, pendapatan masyarakat yang tinggi di Desa Temajok juga belum dapat mengimbangi pelayanan akan kebutuhan dasar seperti listrik dan telepon. Menurut hasil wawancara kepala desa Temjok, saat ini desa masih terbebani pembayaran jaringan listrik dan telepon setiap bulannya sebesar tiga hingga enam juta rupiah. Hal ini merupakan kontradiksi terbalik antara kemampuan masyarakat dengan pembangunan daerah di Kecamatan Paloh.

Terlepas dari fakta yang ada, gambaran ketimpangan tersebut pada prinsipnya selaras dengan teori Williamson (Nurzaman, 2012) bahwa Kecamatan Paloh saat ini telah berada pada fase perkembangan yang cukup baik dimana ketimpangan akan terus meningkat hingga pada titik tertentu dan akan menurun kembali ketika Kecamatan Paloh sudah tumbuh sangat maju.

\subsection{Tipologi Desa Kecamatan Paloh}

\section{A. Tipologi Desa Berdasarkan Aspek Lingkungan Fisik}

Seluruh desa di Kecamatan Paloh merupakan desa pesisir yang masih dipengaruhi oleh pasang surut air laut. Sebagian besar masyarakat menggantungkan hidupnya pada perikanan dan kelautan. Pintu masuk ekonomi Desa Temajok sebagai desa perbatasan selain darat juga berorientasi pada jalur laut.

Selain tergolong desa pesisir, terdapat sebagian kecil wilayah di desa Sebubus dan Temajok bagian selatan merupakan desa perbukitan. Bagian selatan desa Sebubus dan Paloh memiliki kelerengan terjal hingga bergelombang dengan ketinggian $>100 \mathrm{~m}$ dpl. Bagian selatan Desa Sebubus dan Temajok (Daerah perbukitan) tersebut banyak dimanfaatkan untuk tambang batu galian $\mathrm{C}$.

\section{B. Tipologi Desa Berdasarkan Aspek Posisi Geografis Terhadap Pusat Pertumbuhan Kota}


Berdasarkan aspek posisi geografis terhadap pusat pertumbuhan Kota, Hampir sebagian besar karakteristik desa-desa di Kecamatan Paloh masuk dalam kriteria desa di perdesaan yang memiliki hubungan yang cukup baik dengan perkotaan sambas terutama Desa Matang Danau sebagai pintu gerbang utama jalur darat menuju perkotaan Sambas. Dalam konstelasi wilayah yang lebih luas, Kecamatan Paloh berfungsi dalam mendukung kegiatan perikanan karena secara fisik merupakan desa pesisir yang cukup kaya akan hasil laut seperi ikan dan ubur-ubur. Kecamatan Paloh memiliki kepadatan penduduk dan permukiman yang tergolong rendah berkisar $<100 \mathrm{jiwa} / \mathrm{km}^{2}$ dengan hubungan sosial akrab dan memiliki keterbatasan akses terutama jalur darat menuju Desa temajok.

\section{Tipologi Desa Berdasarkan Aspek Posisi Spasial}

Menurut aspek posisi spasial, Seluruh Desa di Kecamatan Paloh (Desa Kalimantan, Matang Danau, Tanah Hitam, Mentibar, Malek, Nibung, Sebubus dan Temajok) merupakan desa yang menyusuri sepanjang pantai. Dengan karakterisitik landai, mata pencaharian dibidang perikanan, perkebunan kelapa dan perdagangan. Desa-desa di Kecamatan paloh meluas dengan cara menyambung yang lama dengan menyusur pantai sampai bertemu dengan desa pantai lainnya. Untuk Desa Malek, Sebubus dan Nibung meskipun secara umum karakteristik spasial masuk dalam tipologi desa yang menyusuri sepanjang pantai, namun ketiga desa tersebut memiliki radius pantai yang cukup lebar yaitu $>500 \mathrm{~m}$. Lihat gambar 1 berikut.

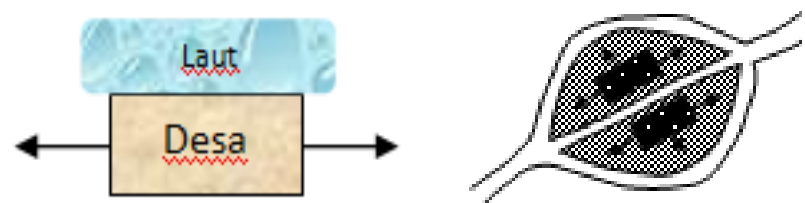

Gambar 1. Diagram Distribusi Pendapatan Masyarakat Masyarakat Kecamatan Paloh

\section{Tipologi Desa Berdasarkan Tingkat Perkembangan Desa}

Adapun tipologi desa berdasarkan tingkat perkembangan desa sebagai berikut:

a. Seluruh desa memiliki kepadatan penduduk $<200 \mathrm{~km} / \mathrm{Km}^{2}$ (skor 1 )

b. Keadaan alam: Hampir sebagian besar desa memiliki kelerengan datar 0-8 (skor 3), kecuali sebagian desa di Matang Danau dan Sebubus (skor 2) dan sebagian besar Temajuk (skor 1) memiliki wilayah dengan kelerengan begelombang hingga terjal.

c. Hampir seluruh orbitasi desa cenderung mengarah ke pusat Kecamatan (skor 2), kecuali Matang Danau yang mengarah ke Perkotaan Sambas (skor 3) dan Temajok kearah Teluk Melano-Malaysia (skor 1).

d. Seluruh desa $>55 \%$ bekerja disektor primer (nelayan dan petani) (skor 2 )

e. Sebagian besa produksi desa mendapatkan output dari hasil perkebunan dan perikanan sebesar 50-100 juta (Skor 2), kecuali Temajok yaitu $>100$ juta skor 3 ) dan Kalimantan $<50$ juta (score 1).

f. Tidak ada adat yang mengikat pada seluruh desa di Kecamatan Paloh (skor 3).

g. Lembaga masyarakat cukup aktif disebagian besar desa (skor 2), kecuali desa Kalimantan, Tanah Hitam dan Mentibar (skor 1) tidak memiliki lembaga masyarakat.

h. Pendidikan masyarakat yang lulus SD antara 50-65\% pada hampir seluruh desa (skor 2), kecuali Desa Nibung dan Sebubus yaitu $>70 \%$ (skor3).

i. Gotong royong pada seluruh desa bersifat laten (skor 1 )

j. Hampir sebagian besar desa memiliki sarana dan prasarana cukup (skor 2), kecuali Desa Kalimantan dengan akses dan keberadaan fasilitas ekonomi yang kurang (skor 1 ) dan Desa Nibung yang sudah lebih baik dibandingkan desa lainnya (skor 3).

Dari hasil analisis diatas, diketahui bahwa Desa Kalimantan memiliki skor total sebesar 21, Desa Matang Danau sebesar 20, Desa Tanah Hitam sebesar 18, Desa Malek sebesar 19, Desa Nibung sebesar 22, Desa Sebubus sebesar 22, Desa Temajok sebesar 17 dan Desa Mentibar sebesar 19. Dengan demikian dapat disimpulkan bahwa seluruh desa yang terdapat di Kecamatan Paloh tergolong Desa Swakarsa. 


\subsection{Kondisi Ekonomi Masyarakat}

\section{A. Pendapatan Masyarakat}

Pendapatan masyarakat sangat berpengaruh terhadap derajat ketimpangan suatu daerah (Pratiwi, 2009). Dari hasil analisis, dapat disimpulkan bahwa sebagian besar masyarakat Kecamatan Paloh sudah berada pada kondisi ekonomi sedang. Dengan demikian dapat diketahui bahwa pembangunan Kecamatan Paloh telah memberikan kontribusi besar bagi kemakmuran rakyat. Lihat gambar 2 berikut.

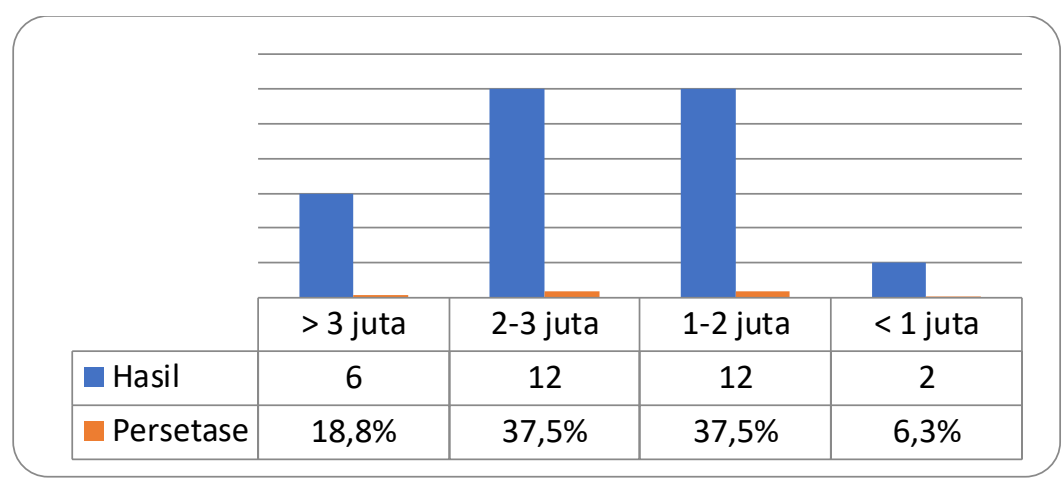

Gambar 2. Diagram Distribusi Pendapatan Masyarakat Masyarakat Kecamatan Paloh

\section{B. Daya Beli Masyarakat}

Berdasarkan UNDP (1995), standar rata-rata daya beli masyarakat adalah sebesar Rp. 1.040.250,-. Pada tahun 2015, rata-rata kemampuan daya beli Masyarakat Kecamatan Paloh adalah sebesar Rp. 1.500.000,-, angka tersebut masih diatas standar yang telah ditetapkan UNDP. Jika dilihat secara keseluruhan dapat diketahui bahwa seluruh wilayah yang ada yang ada di Kecamatan Paloh memiliki pengeluaran rata-rata sangat tinggi. Hal ini mengindikasikan sudah meratanya tingkat pendapatan masyarakat di Kecamatan Paloh.

\subsection{Faktor-Faktor Perkembangan Wilayah}

\section{A. Faktor Sumber Daya Alam}

Menurut Sjafrizal (2012), semakin cepat pertumbuhan ekonomi, maka akan semakin banyak barang sumber daya yang diperlukan dalam proses produksi. Dimana Sumber Daya Alam dan lingkungan mencakup kondisi bentang alam, potensi SDA serta letak geografis.

Berdasarkan hasil amatan diketahui bahwa Kecamatan Paloh memiliki berbagai potensi sumber daya alam berupa hasil laut (ikan dan ubur-ubur) serta perkebunan. Pada Tahun 2014, jumlah hasil tangkap ikan Kecamatan Paloh adalah sebesar 4.400,5 ton, sedangkan ubur-ubur dalam sekali tangkap bisa mencapai 20 ton. Berdasarkan hasil wawancara, hasil perikanan dapat memberikan kontribusi pendapatan daerah kurang lebih hampir 30\% dari pendapatan total. Untuk hasil perkebunan, sama dengan Kabupaten Sambas secara umum bahwa kecamatan Paloh juga memiliki komoditas unggulan di tanaman karet dan lada. Tahun 2014, produksi karet di Kecamatan Paloh adalah sebesar 375,69 Ton dan lada sebesar 172,51 Ton.

Dari hasil analisis komparasi antar seluruh komponen SDA diketahui bahwa $44 \%$ kondisi sumber daya alam dan lingkungan berpengaruh kuat, 33\% berpengaruh sedang, $16 \%$ kurang berpengaruh serta $7 \%$ tidak berpengaruh terhadap perkembangan wilayah. Dengan demikian, faktor SDA dan lingkungan berpengaruh kuat terhadap perkembangan wilayah Kecamatan Paloh sebagai salah satu wilayah perbatasan Kabupaten Sambas.

\section{B. Faktor Sumber Daya Manusia}

Salah satu aspek yang mempengaruhi perkembangan suatu wilayah adalah kualitas manusia (Kanthi, 1998; Affendi, 2005). Gambaran kualitas sumber daya manusia dapat diukur melalui tingkat pendidikan, kesehatan dan kesadaran masyarakat. Tingkat pendidikan, masyarakat Paloh masih cenderung rendah. 
Menurut data statistik, diketahui bahwa kurang lebih hanya sebesar $47 \%$ masyarakat Paloh yang telah berhasil mengenyam pendidikan 9 (embilan tahun).

Meskipun demikian, angka melek huruf dari tahun ketahun menunjukan kecendrungan yang meningkat. Masyarakat yang sadar akan pentingnya pendidikan di Paloh juga sudah cukup baik terbukti dengan semakin banyaknya angka masyarakat yang mengenyam pendidikan tinggi. Berdasarkan angka kesehatan masyarakat, kecamatan Paloh tergolong tinggi. Hal tersebut dapat dilihat dari rendahnya angka penyakit serta kematian ibu dan anak di Kecamatan Paloh. Sementara untuk kondisi kesadaran masyarakat dapat digambarkan dengan cukup baiknya partisipasi masyarakat dalam pembangunan di Kecamatan Paloh.

Dari hasil komparasi antar ketiga komponen tersebut diketahui bahwa $23 \%$ kondisi sumber daya manusia berpengaruh kuat, 33\% berpengaruh sedang, 31\% kurang berpengaruh serta $13 \%$ tidak berpengaruh terhadap perkembangan wilayah. Dengan demikian, faktor SDM cukup berpengaruh terhadap perkembangan wilayah Kecamatan Paloh sebagai salah satu wilayah perbatasan Kabupaten Sambas.

\section{Faktor Infrastruktur}

Kondisi perkembangan wilayah dalam mengurangi disparitas juga dipengaruhi oleh aspek ketersediaan infrastruktur sebagai magnet pertumbuhan (Affendi, 2005). Kondisi infrastruktur digambarkan melalui kondisi jalan, keberadaan fasilitas serta utilitas. Menurut hasil pengamatan, dapat dilihat bahwa kondisi jalan di Kecamatan Paloh cukup bervariasi. Sebesar $30 \%$ jalan sudah diperkeras dengan aspal dalam kondisi baik terutama ditengah Kecamatan, namun pada wilayah bagian timur (Desa Kalimantan) dan Timur (ujung desa Sebubus hingga jalan menuju Temajok) merupakan jalan dengan perkerasan aspal hingga tanah dalam kondsi buruk. Pada pelayanan fasilitas dan utilitas di Kecamatan Paloh juga cukup beragam.

Pusat fasilitas tentunya berada pada ibu kota kecamatan yang terletak di tengah kecamatan (Liku) yang berbatasan antara Desa Sebubus dan Nibung. Untuk pelayanan utilitas air bersih masyarakat Paloh banyak memanfaatkan air hujan untuk minum dan sumur untuk keperluan MCK (belum terdapat PDAM). Untuk listrik dan komunikasi hampir seluruh rumah di Kecamatan Paloh sudah dilayani PLN dan menara-menara komunikasi meskpun kualitas jaringannya belum terlalu baik.

Dari hasil komparasi, diketahui bahwa 15\% kondisi infrastruktur berpengaruh kuat, 36\% berpengaruh sedang, 36\% kurang berpengaruh serta $14 \%$ tidak berpengaruh terhadap perkembangan wilayah. Dengan demikian, faktor ketersediaan infrastruktur terutama akses kurang berpengaruh terhadap perkembangan wilayah Kecamatan Paloh sebagai salah satu wilayah perbatasan Kabupaten Sambas.

\section{Faktor Peluang Usaha}

Menurut Budianta (2010), rendahnya peluang usaha merupakan salah satu hambatan dalam pembangunan wilayah desa terutama akses pasar dalam mendukung pengembangan sektor utama yaitu pertanian/perikanan. Syahza dan Suarman (2013), mengatakan bahwa dalam peluang usaha masyarakat desa dipengaruhi oleh beberapa hal yaitu dukungan pemerintah, keberadaan industri rumah tangga dan pangsa pasar.

Keberadaan home industy di Kecamatan Paloh masih didominasi pada usaha-usaha temporari berdasarkan musim. Keberadaan industri mikro dan rumah tangga di Paloh tidak terlalu signifikan berkembang. Saat ini beberapa usaha mikro yang terdapat di Paloh cenderung pada usaha makanan yang berbasis pada hasil laut seperti ikan kering, asinan ubur-ubur dan makanan hasil ikan lainnya. Sedangkan untuk kebijakan pemerintah dalam usaha pengembangan usaha bagi masyarkat Paloh menurut hasil wawancara sudah cukup banyak mendapat dukungan. Hal ini dibuktikan dengan berbagai pinjaman modal dan kebijakan-kebijakan terkait koperasi desa.

Dari hasil komparasi diketahui bahwa $29 \%$ peluang usaha berpengaruh kuat, $23 \%$ berpengaruh sedang, $36 \%$ kurang berpengaruh serta $11 \%$ tidak berpengaruh terhadap perkembangan wilayah. Dengan demikian, 
faktor peluang usaha kurang berpengaruh terhadap perkembangan wilayah Kecamatan Paloh sebagai salah satu wilayah perbatasan Kabupaten Sambas.

\section{E. Faktor Demografis dan Mobilitas}

Salah satu faktor yang mempengaruhi ketimpangan wilayah adalah perbedaan demografis dan pergerakan orang dan barang yang merupakan implikasi dari mobilitas masyarakat Sjafrizal (2012). Gambaran demogafis dapat dilihat dari perbedaan pertumbuhan dan kepadatan penduduk sementara mobilitas sosial dapat dilihat dari lajunya pergerakan orang dan barang.

Pertumbuhan penduduk rata-rata Kecamatan Paloh adalah 1,4\% pertahun (lebih tinggi dari Kabupaten Sambas yaitu $1,2 \%$ pertahun), namun kepadatan penduduknya $\left(21,77 \mathrm{jiwa} / \mathrm{km}^{2}\right)$ tergolong rendah dibandingkan dengan Kabupaten Sambas (104 jiwa/ $\left./ \mathrm{Km}^{2}\right)$. Selain itu, dilihat dari pergerakan orang barang di Kecamatan Paloh secara keseluruhan memang kurang mempengaruhi perkembangan wilayah. Hal tersebut disebabkan oleh akses yang kurang mendukung untuk menunjang mobilitas orang barang keluar dan masuk Kecamatan. Namun demikian untuk desa Temajok, mobilitas orang barang terutama yang mengarah keluar dan masuk dari Teluk Malano Malaysia sangat tinggi. Hal ini disebabakan karena jarak yang cukup dekat dan akses yang mudah sehingga konektivitas terutama untuk kepentingan kegiatan perdagangan jasa serta hubungan sosial sangat tinggi.

Dari hasil komparasi diketahui bahwa 21\% faktor, $42 \%$ berpengaruh sedang, 33\% kurang berpengaruh serta $4 \%$ tidak berpengaruh terhadap perkembangan wilayah. Dengan demikian, faktor demografi dan mobilitas cukup berpengaruh terhadap perkembangan wilayah Kecamatan Paloh sebagai salah satu wilayah perbatasan Kabupaten Sambas.

\section{KESIMPULAN}

Secara umum tidak terjadi disparitas di Kecamatan Paloh, namun nilai IW dalam menunjukan disparitas suatu wilayah di Kecamatan Paloh semakin meningkat selama 5 (lima) tahun terkahir. Kecamatan Paloh tergolong dalam kecamatan pesisir dataran rendah di perdesaan dengan klasifikasi tergolong Desa Swasembada. Hal ini menunjukan bahwa kondisi social ekonomi di Kecamatan Paloh sudah menunjukan gambaran yang stabil. Faktor-faktor menyebabkan semakian meningkatnya disparitas di Kecamatan Paloh adalah ketersedaan infrastruktur terutama akses jalan dan sarana prasarana pengembang ekonomi sehingga menyebabkan rendahnya peluang usaha dan mobilitas orang barang di Kecamatan Paloh.

\section{DAFTAR PUSTAKA}

PP No. 72 Tahun 2005 Tentang Pemerintahan Desa

UU No 26 Tahun 2007 Tentang Penataan Ruang

PP No 26 Tahun 2008 tentang Rencana Tata Ruang Wilayah Nasional

Affandi, Anwar. (2005). Ketimpangan Pembangunan Wilayah Perdesaan. Tinjauan Kritis. P4Wpress. Bogor.

Anwar, A. (2001). Pembangunan Wilayah Perdesaan dengan Desentralisasi Spatial Melalui Pembangunan

Agropolitan yang Mereplikasi Kota-Kota Menengah dan Kecil. Makalah disampaikan pada Pembahasan Proyek Perintisan Pengembangan Wilayah Perdesaan, 15 November 2001. Jakarta

Budianta, Aziz. (2010). Pengembangan Wilayah Perbatasan Sebagai Upaya Pemerataan Pembangunan Wilayah Wilayah Di Indonesia. Jurnal SMARTek. Vol 8, No 1, Hal 72-82.

Glasson, John. (1977). Pengantar Perencanaan Regional. Terjemahan Paul Sitohang. LPEM-FEUI. Jakarta.

Hadiwijoyo, S. (2011). Perbatasan Negara Dalam Dimensi Hukum Internasional. Graha Ilmu. Yogyakarta.

Hayami, Y dan V.W. Ruttan. (1971). Agriculture Development: An International Perspective. The John Hopleins Press. Baltimore and London.

Husnadi. (2006). Menuju Model Pengembangan Kawasan Perbatasan Daratan Antar Negara. Tesis tidak diterbitkan. Jurusan Perencanaan Wilayah dan Kota. Universitas Diponegro. Semarang. 
Kanthi, Sri. (1998). Identifikasi Permasalahan Kesenjangan Wilayah. Kasus: Tiga Desa Sebagai Masukan Pengembangan Wilayah Kabupaten Tulungagung Bagian Barat Selatan. Jurnal Plannit. Edisi Pertama. Institute Teknologi Nasional. Malang.

Kartasasmita, G. (1996). Pembangunan Untuk Rakyat. Memadukan Pertumbuhan dan Pemerataan. Penerbit Pustaka Cidesindo.

Kuncoro, M. (2004). Pertumbuhan Ekonomi Dan Ketimpangan Antar Wilayah dalam buku Otonomi Dan Pembangunan Daerah. Erlangga. Jakarta.

Kuznets, S. (1955). Economic Growth and Income Inequality. American Economic Review. 45, hal 1-28.

Muhadjir, N. (1989). Metodologi Penelitian Kualitatif. Bayu Indra Grafika. Yogyakarta.

Murty, S. (2000). Regional Disparities: Need and Measure for Balanced Development In Shukla, (Ed). Regional Planning dan Sustainable Development. Kanishka Publishers, Distributor. New Delhi-110 002

Muta'ali, L. (2013). Pengembangan Wilayah Perdesaan (Perspektif Keruangan). Badan Penerbit Fakultas Geografi (BPFG) UGM. Yogyakarta.

Muta'ali, L. (2014). Pengembangan Kawasan Perbatasan. Badan Penerbit Fakultas Geografi (BPFG) UGM. Yogyakarta.

Pratiwi, Nana Novita. (2015). Ketimpangan Pembangunan Ekonomi Masyarakat Wilayah Kabupaten Malang. Prosiding Semiar Nasional, PIPT. ISBN 9978-602-8355-41-4.

Sjafrizal. (2012). Ekonomi Wilayah dan Perkotaan. RajaGrafindo Persada. Jakarta

Sugiyono. (2005). Memahami Penelitian Kualitatif. Alfabeta. Bandung.

Sumpeno, W. (2011). Perencanaan Desa Terpadu. Edisi Kedua. Read. Aceh

Syahza, Almasdi dan Suarman. (2013). Strategi Pengembangan Daerah Tertinggal Dalam Upaya Percepatan Pembangunan Ekonomi Perdesaan. Jurnal Ekonomi Pembangunan. Vol 14. No 1. Hal 126-139.

Tarigan A. (2003). Rural-Urban Economic Linkage. Jurnal Forum Inovasi Capacity Building and Good Governance. Jakarta.

Thontowi, J. (2009). Masyarakat Marjinal Perbatasan di Kalimantan Barat. Upload 15 September 2009.

Todaro, Michael P. (2000). Pembangunan Ekonomi di Dunia Ketiga. Edisi Ketujuh. Penerbit Erlangga. Jakarta. Umbu, Johny. (2003). Strategi Pengembangan Wilayah Terbelakang, Satu Alternatif Penganggulangan Masalah Kesenjangan. Jurnal Plannit. Tahun 2001. Edisi Pertama. Institute Teknologi Nasional. Malang. UNDP. (1995). Human Development Report. Oxford University Press. New York.

Williamson, J,G. (1965). Regional Inequality and The Process of National Development, a Description of Pattern, Economic Development and Cultiral Change. Vol.XXXVII. No 27.

Yayuk dan Mangku. (2003). Sosiologi Perdesaan. Lappera Pustaka Utama. Yogyakarta. 